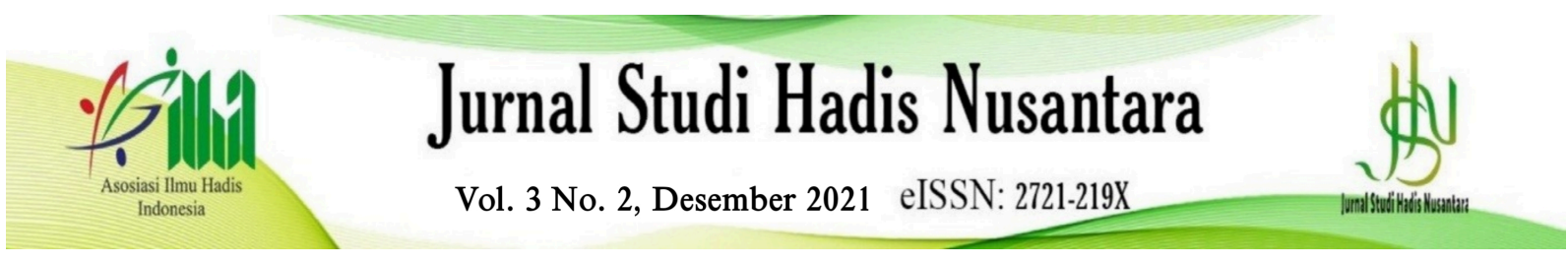

\title{
Studi Analisis Hadis Țibal-Nabawi dan Signifikansinya dalam Kesehatan Tubuh
}

\author{
Arif Friyadi \\ IAIN Kudus \\ Email: ariffriyadi1986@gmail.com
}

\begin{abstract}
Abstrak
Artikel ini bertujuan untuk membahas hadis apa saja yang mendasari pengobatan ala Nabi serta kandungan obat herbal ala Nabi dalam dunia kesehatan modern. Meski zaman modern teknologi kesehatan bergerak secara drastis, namun banyak juga seorang muslim atau non muslim yang masih memanfaatkan obat herbal atau thibb al nabawi sebagai jalan pengobatan. Didasari living sunnah banyak kalangan muslim yang masih menjadikan thib al Nabawi sebagai jalan alternatif untuk menjaga kesehatan tubuh. Penulis menggunakan metode analisis hadis yang dikumpulkan dari beberapa kitab hadis induk seperti Kitab Bukhari dan Muslim melalui software digital pencarian hadis Jawami'ul Kalim. Temuan menunjukkan bahwa ideal moral yang terkandung dalam ini adalah obat herbal ala Nabi mengandung banyak khasiat untuk kesehatan jika seorang rajin mengkonsumsinya.
\end{abstract}

Kata Kunci : Tibal-Nabawi, herbal, pengobatan alternatif

\section{A. Pendahuluan}

Dalam rangka pengajaran pada ummatnya, Rasul memberikan penjelasan yang semua itu tertulis dalam kitab-kitab hadis. Hadis selain menjadi petunjuk penting bagi ummat Islam, juga berfungsi sebagai penguat (bayān taqrïr) dan penjelas (bayān tafsir) serta penentu hukum (bayān tasyri) bagi Al-Qur'an. ${ }^{1}$

Praktik keseharian ummat Islam baik bersifat ibadah ataupun mu'amalah selain merujuk pada Al-Qur'an juga merujuk pada hadis yang disabdakan Rasulullah. Secara

\footnotetext{
${ }^{1}$ Muhammad 'Ajjaj Al-Khatib, Ushulu Al Hadis (Bairut: Dar al Fikr).
}

realitas yang ada, praktik penyembuhan penyakit misalnya, ummat Islam pada umumnya masih menggunakan cara yang dilakukan oleh Rasulullah.

Padahal jika melihat kecanggihan teknologi di bidang kesehatan setiap harinya mengalami kecanggihan yang luar biasa. Namun kecanggihan teknologi kesehatan ini berbanding terbalik jika dilihat dengan kemampuan finansial masyarakat menengah ke bawah. Oleh karenanya banyak sekali yang 
memanfaatkan tradisi yang dibawa Rasulullah dalam hal pengobatan. ${ }^{2}$

Pengobatan ala Nabi merupakan salah satu cabang dari penerapan maqasid syariah dalam rangka hifdzu al-nafs (menjaga diri dari penyakit). Pada dasarnya pengobatan secara umum dalam hadis Nabi terbagi menjadi dua; pengobatan tubuh dan pengobatan hati. Pengobatan tubuh sendiri menurut hemat penulis adalah bersumber dari inisiatif Rasul sebagai manusia. Melalui observasi dan kebiasaan yang diterapkan waktu itu Rasul berusaha menyampaikan pengobatan Islami yang pastinya sedikit berbeda dari kebiasaan pengobatan Jahiliyyah. sementara itu, pengobatan hati bersumber pada wahyu Allah Swt. Secara spesifik Rasul telah menjelaskannya dalam beberapa hadisnya tentang pengobatan.

Sayangnya beberapa pembaca salah mengartikan teks hadis yang disampaikan oleh Rasul sehingga banyak yang keliru dalam menafsirkan teks hadis pengobatan Rasul. Beberapa juga menjadikan pengobatan Rasul adalah sebagai dasar paten yang harus diterapkan dalam pengobatan, padahal itu adalah alternatif Nabi dalam menjaga ummatnya dari penyakit. Bukan sumber paten pengobatan yang harus selalu diaplikasikan.

Dalam penelitian ini penulis menggunakan software pencarian hadis di PC bernama al Jami' Li al Hadis anNabawi. Dengan cara mencari satu persatu hadis yang berkenaan dengan kesehatan dan mencarinya. Setelah itu mengkomparasikan dengan metode kesehatan terkini tentang kandungan hadis-hadis itu.
2 Muhammad Fatahilah, 'Klinik Pengobatan Thibbun Nabawi Di Kota Pontianak', Jurnal Online Mahasiswa Arsitektur Universitas Tanjungpura, 4.2 (2016), 109.

3 Alfandi Ilham Safarsyah, 'Hadis Nabi SAW Tentang Obat Dalam Tinjauan Ilmu Kedokteran

\section{B. Pembahasan}

\section{Pengertian Thib al nabawi (Pengobatan Ala Nabi) \\ Thibbunnabawi adalah perkataan} dan tindakan Nabi Islam Muhammad yang merupakan usaha Nabi dalam rangka mengobati penyakit serta diagnosa awal dan menjaga kebersihan untuk menjelaskan tradisi-tradisi yang berkembang saat itu. ${ }^{3}$

Istilah ini telah muncul pada abad ke-13 M yang dikemukakan oleh para Dokter Muslim. Hal ini menunjukkan ilmuilmu kedokteran Islam pada abad itu telah muncul sebagai pedoman ummat muslim dalam mencari alternatif pengobatan dari berbagai penyakit yang muncul kala itu. Sehingga hal ini akan menangkal kesyirikan dan takhayul yang juga muncul di tengah masyarakat Jahiliyyah.

Pengobatan diambil dari kata الطب yang secara bahasa diartikan sebagai pengobatan tubuh dan hati. Hal ini diambil dari yang bisa berarti lembut, ambisi, atau pintar dalam urusan pengobatan. ${ }^{4}$

Sementara dalam terminologi kata berarti ilmu yang berkaitan dengan pengobatan dan penyembuhan suatu penyakit. Pengobatan ala Nabi seperti yang disampaikan oleh Mu'taz al Khatib; beberapa hadis Nabi Saw yang berkaitan dengan pengobatan dalam penyembuhan, obat atau apapun dalam diri manusia.

Dari pengertian itu, dapat kita tarik kesimpulan bahwa pengobatan Nabi terbagi menjadi dua; satu berkaitan dengan pengobatan hati dan yang kedua berkaitan dengan badan manusia.

\section{Macam-Macam Sunnah Jika Ditinjau Dari Aspek Legitimati Syari'at Allah ataupun Manusiawi. Sunnah dalam syari'at Islam}

Modern', Al-Dzikra: Jurnal Studi Ilmu Al-Qur'an Dan Al-Hadis, $12.2 \quad$ (2019), 165-88 - https://doi.org/10.24042/al-dzikra.v12i2.2079.

${ }^{4}$ Ibnu Mundzir, Lisan Al Arab (Bairut: Dar el Shadir). 
mempunyai kedudukan tinggi karena sunnah adalah sumber hukum Allah yang kedua setelah Al-Qu'ran. Sunnah mempunyai peran yang cukup jelas dalam menjelaskan Al-Qur'an dan menafsirinya baik itu mengkhususkan Al-Qur'an, memberi keumuman Al-Qur'an dan menjelaskan hukum-hukum yang belum termaktub dalam Al-Qur'an.

Namun tidak semua sunnah dapat dikategorikan sebagai sumber hukum yang harus dipatuhi dan dijalankan teksnya. Karena sisi lain dari Rasulullah adalah seorang manusia biasa yang tentu beberapa kebiasaan sebagai manusia biasa sama seperti manusia lainnya. Dari sini AlDahlawi ${ }^{5}$ menjelaskan secara umum peran dari sunnah terbagi menjadi dua:

a. Sumber dari syari'ah yang tentu dapat disandarkan kepada wahyu Allah. Seperti perintah Rasul kepada sahabatnya "Shalatlah seperti kalian melihatku shalat".

b. Bukan perkara yang harus disampaikan karena mengandung unsur manusiawi. Sebagai contoh hadis;

$$
\text { فشذو "إنما أنا بشر، إمرتكم بشيئ من دينكم }
$$

"Sesungguhnya aku manusia biasa, jika kalian aku perintahkan berkaitan dengan agama kalian maka ambillah. Namun jika kalian aku perintahkan berdasarkan pendapatku maka aku manusia biasa".

Pengakuan ini tentu mendasari bahwa Nabi merupakan manusia biasa yang tidak lepas dari kebiasaan manusia biasa seperti makan, minum, pergi ke pasar, merasa lapar dan masih banyak lagi.

Bahkan Muhammad bin Al Asyqar ${ }^{6}$

\footnotetext{
${ }^{5}$ Syah Wali al Dahlawi, Hujjah Al Balgihah (Cairo: Dar el Jail, 2020).
}

menyebutkan bahwa sunnah terbagi menjadi 7 hal;
1. Al-Fi'lu
al-Jabali
(Perbuatan

Manusiawi) seperti ketika Rasul senang mukanya bercayaha, ketika marah mukanya memerah, tidak suka makan hewan $d z a b$, suka makan bubur tsarid, tidak suka pembunuh Hamzah. Semua itu adalah perbuatan manusiawi yang berdasarkan kepada nafsu seorang manusia.

2. Al-fi'lu al-'Adi (perbuatan kebiasaan umum) seperti halnya memakai jubah, imamah, sandal, bermu'amalah dengan dinar dan dirham, memanjangkan rambut dan mengadakan walimah nikah di rumahnya. Semua ini adalah kebiasaan yang berlaku ketika zaman itu dan berlanjut sampai sekarang.

3. Al-Fi'lu al-Dunyawiyyah (Perbuatan berdasarkan duniawai). Hal ini seperti minum obat tertentu, bekam di kepala, menanam tanaman tertentu, bedagang, gembala kambing, berperang dengan senjata tertentu dan menaiki hewan tertentu. Maka semua ini tidak dikatakan sebagai sunnah yang wajib dilaksanakan.

4. Al-Fi'lu Khariqul al-Adat (perbuatan yang di luar kebisaan menusia biasa atau kita kenal sebagai mu'jizat). Seperti mengeluarkan air dari sela jari, memberi makan satu panci untuk ribuan orang dan membelah bulan.

5. Al-Khasa'is An-Nabawi (Kekhususan Nabi) perbuatan ini tidak bisa diikuti oleh ummatnya karena bukan termasuk sunnah, malah haram jika mengikutinya; seperti menikah lebih dari 4 wanita, puasa wishal (nyambung dari subuh hingga berakhir subuh), wajib shalat malam, haram menerima shadaqah, dan tidak bersyair.

6. Al-Fi'lu al-Bayāni (perbuatan penjelas) seperti menjelaskan tata cara shalat,

${ }^{6}$ Al Azhar Univ. Cairo Muhammad Sulaiman Al أفعال الرسول صلى الله عليه Asyqar, 'Noor-Book.Com وسلم ودلالتها على الأحكام الثرعية.Pdf’ (Cairo: Muassasah al Risalah). 
puasa, haji dan segala syari'at yang terdapat dalam Al Qur'an.

7. Al-Fi'lu al-Imtitsāli (Perbuatan yang wajib dicontoh) Seperti menjalankan sujud dengan 7 anggota badan, perintah Allah menjalankan amanah, mencegah kedzaliman, memotong tangan bagi orang yang mencuri dan lainnya.

\section{Hadis-Hadis \\ Thibbunnubuwwah \\ Antara Kewajiban dan Anjuran}

Meski pengobatan Nabi adalah hal baik diterapkan dalam kehidupan muslim, namun para ulama' dalam menyikapi sunnah thibbunnuwwah (pengobatan ala Nabi) berselisih pandang dalam menetapkannya. Apakah sunnah pengobatan Nabi serta merta harus dilaksanakan oleh seluruh ummat Islam ataukah hanya anjuran saja. Mengingat beberapa sunnah pengobatan ada yang menggunakan teks bernada amar (perintah).

Lalu jika tidak melaksanakan pengobatan itu apakah seorang muslim akan berdosa? Jika menggunakan pengobatan selain pengobatan itu apakah dikatakan sebagai perbuatan bid'ah atau berdosa? Yusuf al Qardlawi dalam kitabnya mengatakan bahwa sunnah yang bernada amar (perintah) bukan berarti serta merta berimplikasi kepada kewajiban, namun juga ada yang berarti mubah, sunnah, mencegah dan sebagai ibrah berdasarkan hadis lain yang menguatkannya. ${ }^{7}$

Hal itu dikuatkan oleh Dr. Fathi Addura ${ }^{8}$ yang mengatakan; bukanlah menjadi kewajiban pelaksanaan hadis yang bernada amar (perintah) karena ada maknamakna lain yang di antaranya; wajib, sunnah, mubah, memberi contoh, intimidasi, memulyakan dan takjub). Sebagai contoh Rasul mengatakan dalam hal pengobatan menggunakan habbah sauda' (jinten hitam):

\footnotetext{
${ }^{7}$ Dr. Yusuf al Qardhawi, 'Dirasah Fi Al Fiqhi Maqasid Al Syari'ah'(Cairo: Dar el Syuruq).
}

$$
\text { "عليكم بهذه الحبة السوداء فإن فيها شفاء من كل }
$$

"Tetaplah kalian menggunakan jinten hitam karena di sana terdapat penyembuh dari segala penyakit kecuali racun" (Sunan Atturmudzi 2041)

Hadis ini bukan berarti kewajiban ummat Islam untuk menjalankan perintah ini karena ini hanyalah anjuran. Karena ada beberapa hadis yang menunjukkan hal ini:

$$
\text { "إن فى الحبة السوداء شفاء من كل داء إلا سام" }
$$

Sesungguhnya dalam jinten hitam terdapat kesembuhan dari setiap penyakit.

Ibnu Qayyim dalam menyikapi perintah hadis pengobatan Nabi ini mengatakan; sesungguhnya Rasulullah hanya diutus untuk penunjuk hidayah kepada Allah, mengenalkan tentang Allah, penjelas untuk ummat dalam perintah ataupun larangan. Adapun untuk pengobatan badan Rasul hanya berinisiatif bukan perintah penyempurna syari'at Allah.

\section{Macam-Macam Hadis yang Tentang Thibbunnubuwah dan Implikasinya Terhadap Kesehatan}

Menjaga kesehatan badan merupakan hal yang urgensi sehingga agama dan syariat memerintahkannya. Di dalam Al Qur'an terdapat banyak sekali ayat-ayat yang berhubungan dengan kesehatan dan menjaga diri dari penyakit. Karena itu dalam Maqasid Syari'ah pengobatan adalah hal yang wajib dikerjakan oleh dalam rangka menjaga diri dan akal. Sementara tidak merusak badan adalah perkara yang dilarang oleh agama.

Dalam Al Qur'an Allah menyebutkan:

$$
\text { وإذا مرضت فهو يشفين (الشعراء : 82) }
$$

"Ketika aku sedang sakit Allahlah yang menyembuhkanku."'(Assyu'ara 82)

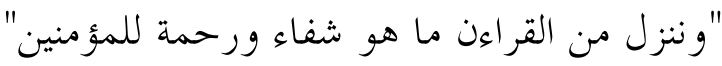

\footnotetext{
${ }^{8}$ Dr. Fathi Al duraini, 'Al Manahij Al Ushuliyyah Fi Al Ijtihad Bi Al Ra'yi Fi Tasyri' Al Islami' (Cairo: Muassasah al Risalah).
} 


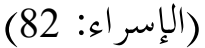

"Adapun hadit-hadis yang menunjukkan pengobatan Nabi secara spesifik adalah sebagai berikut;" (Al Isra' 82)

Dari Omasa bin Syarik, seorang A'rabi mengatakan kepada Rasulullah; Wahai Rasul, apakah kami harus berobat? Rasul bersabda;

$$
\begin{aligned}
& \text { "نعم يا عباد الله تداووا، فإن الله لم يضع داء إلا } \\
& \text { وضع له شفاء أو دواء، إلا داء واحد. فقالوا يا } \\
& \text { رسول الله ما هو قُ قال: الهرام." }
\end{aligned}
$$

"Hai hamba Allah, berobatlah kalian! Allah tidak menciptkankan suatu penyakit kecuali Allah menciptakan obat dari penyakit tersebut. Kecuali satu penyakit yang tidak bisa sembuh. Para sahabat kembali bertanya; apakah penyakit itu, wahai Rasul? penyakit itu adalah pikun. (Sunan al Turmudzi)

Dari Abu Hurairah RA. Rasul bersabda:

$$
\text { "ما أنزل الله داء إلا أنزل له شفاء" }
$$

"Allah tidak menurunkan seuatu penyakit kecuali Allah menurunkan kepadanya obat" (Shahih Bukhari No. 5678)

Dari hadis di atas Rasul memberikan penjelasan bahwa tidak ada penyakit yang tidak bisa sembuh. Jika memang sampai sekarang ada beberapa penyakit yang sulit untuk disembuhkan artinya bukan hadis ini salah, namun manusia belum bisa mencapai keilmuan tentang penyakit tersebut.

\section{a. Pengobatan Menggunakan Madu}

Selama berabadab-abad lamanya, madu sering dikaitkan dengan berbagai manfaat kesehatan manusia. Cairan manis ini selama ratusan tahun telah digunakan dalam berbagai macam pengobatan. Salah satunya adalah obat pencernaan dan ketidakseimbangan pada tubuh. Sebagaimana sabda berikut:

Artinya: Dari Abu sa'id Ra. Sesungguhnya

9 Resa Eka Ayu Sartika, 'No Title', 2020 <https://health.kompas.com/read/2020/07/08/19340 seorang datang kepada Rasul dan berkata: "saudaraku mengeluh perutnya sakit." Bersabda Rasul: "Minumilah dia madu," Kemudian datang untuk kedua Rasul msih memintanya untuk meminumi madu, begitu sampai tiga kali. Laki-laki itu mengatakan; "saya sudah melaksanakannya, namun dia tetap saja mengeluh. Rasul bersabda: Allah benar dan perut saudaramu yang berbohong, tetap minumilah madu. Setelah keempatnya perut saudara laki-laki orang tersebut akhirnya sembuh. (Hadis Bukhari: 5360 dan Muslim: 2217)

Dalam sebuah artikel Harian Kompas pada tanggal 08 Juli 2020 mengatakan, "komsumsi madu telah digunakan oleh manusia sejak 8000 tahun lalu. Hingga kini, madu dipercaya sebagai salah satu obat yang baik untuk tubuh. Di antara manfaatnya adalah; mengobati batuk, membuat tidur semakin nyaman, menurunkan tekanan darah, menurunkan kadar kolesterol tubuh, menghilangkan ketombe rambut dan masih banyak lagi. ${ }^{9}$

\section{b. Pengobatan Nabi dari Panas dengan Kompres}

Meski kompres adalah anjuran Rasul berabad-abad silam, namun untuk meringankan rasa panas dalam tubuh, modern ini masih banyak orang yang masih menggunakan cara ini.

Diriwayatkan dari Asma' binti Abu Bakar setiap kali ada seorang perempuan yang panas datang kepadanya maka dia akan mengambil air untuk dikompreskan ke keningnya. Asma' mengatakan: Rasul memerintahkan kami untuk mengompres dengan air. (shahih Al Bukhari, No. 5724)

$$
\begin{aligned}
& \text { أن النبي - صلى الله عليه وسلم - قال) : الحمى } \\
& \text { من فيح جهنم فأبردوها بالماء ( رواه البخاري، } \\
& \text { وأمر - صلى الله عليه وسلم - عندما اشتدت عليه } \\
& \text { الحمى في مرض وفاته أن يصب عليه من سبع }
\end{aligned}
$$

0368/10-manfaat-madu-untuk-kesehatantubuh?page $=$ all $>$. 


$$
\text { قرب. }
$$

Artinya: sesungguhnya Nabi Saw. berkata: panas adalah dari uap neraka jahannam, maka padamkanlah dengan air. (Diriwayatkan Bukhari). Rasulullah ketika menjelang kematiannya meminta Aisyah untuk mengompres beliau dengan 7 bejana. (Shahih Al Bukhari Kitab Bad'ul Khalqi Sifatunnar 124/4)

Menurut beberapa artikel kesehatan beberapa dokter masih menyarankan metode thibbunnubuwah pada pasien panas. Kompres selain dapat menurunkan suhu tubuh, kompres dingin juga dapat meredakan sakit kepala, nyeri, hingga pembengkakan pada tubuh Anda. ${ }^{10}$

Ketika seorang terkena demam dalam tubuhnya, hal yang dapat ia lakukan adalah dengan mengkompres. Namun sayangnya tidak sedikit orang yang masih bingung menentukan kompres turun panas. Caranya adalah basahi handuk yang dengan air, lalu peras air yang menempel dalam handuk. Masukkan handuk tersebut ke kulkas sampai dirasakan sudah dingin. Keluarkan dari kulkas dan letakkan di atas dahi, pipi atau leher.

c. Pengobatan Nabi menggunakan Habbah Sauda' atau Jinten Hitam

Penggunaan habbah sauda' pernah dilakukan oleh Rasulullah Saw. sebagaimana sabdanya:

$$
\text { فى الحبة السوداء شفاء من كل داء }
$$

"Dalam Habbah Sauda' jinten dapat menyembuhkan setiap penyakit kecuali bisa." (shahih Muslim no. 2041)

Dalam kitab Shahih Bukhari No. Hadis 5687 juga disebutkan dengan redaksi yang hampir sama:

Artinya: "diceritakan oleh Abdullah bin Abi Syaibah: Kami dicertakan oleh

10 Salis Anisa, 'No Title', Sehatq.Com, 2020 <https://www.sehatq.com/artikel/kompres-penurun-
Ubaidillah: dari Mansur, dari Khalid bin Sa'id dia berkata: kami keluar bersama Rasulullah. Di antara kami ada Ghalib bin Abjar yang sedang sakit di tengah jalan. Kami sampai di Madinah dia masih juga sakit hingga dibimbing Ibnu Abi 'Atiq. Dia berkata: kalian manfaatkanlah Habbah Sauda' ambillah 5 atau 7 dan potonglah dengan mancampurnya dengan minyak lalu meminumkannya, karena sesungguhnya Sayyidahh 'Aisyah mendengar dari Nabi yang berkata: "Sesungguhnya Habbah saudah terdapat pengobat dari setiap penyakit kecuali Saam. Aku bertanya apa itu 'saam'? Dia menjawab: kematian."

Dari kedua hadis di atas dapat kita simpulkan khasiat jinten hitam atau habbah sauda' yang ketika waktu itu sangat dimanfaatkan sebagian besar para sahabat Rasulullah. Meski beberapa ulama berkomentar jika jinten hitam tidak bisa menyembuhkan seluruh penyakit masa kini. Penyakit mengalami perubahan dengan perubahan musim dan lingkungan serta makanan yang dikonsumsi. Sehingga tidak bisa dikatakan pada saat ini jika jinten hitam dapat menyembuhkan seluruh penyakit. ${ }^{11}$

Terlepas dari perbedaan pendapat itu, Habbah Sauda' sebenarnya adalah salah satu obat herbal yang masih eksis hingga saat ini sering juga dikenal dengan sebutan jintan hitam. Menurut Abdullah Umar Bumasa, tanaman ini banyak dijumpai di negara-negara Tepi Laut Tengah, Eropa Tengah dan Asia Barat. Jenis dari tanaman tersebut pun sangat bermacam-macam.

Obat ini di Indonesia disebut sebagai jintan hitam. Obat herbal ini mempunyai banyak khasiat, di antaranya adalah; mempunyai efek melawan mikroba, mengatur tekanan darah dan mengatasi penyakit asma.

\section{d. Pengobatan Menggunakan Susu dan Kencing Onta}

panas-dan-cara-lain-untuk-mengatasi-panasdemam>.

${ }^{11}$ Safarsyah. 
Pengobatan berikutnya adalah obat herbal melalui susu onta, seperti yang disabdakan oleh Rasulullah:

$$
\text { إشربوا ألباها }
$$

"Minumlah susu onta" (Shahib Bukhari 2042)

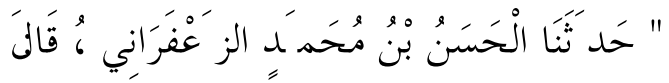

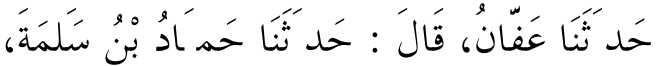

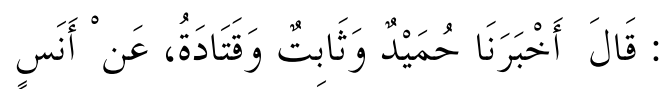

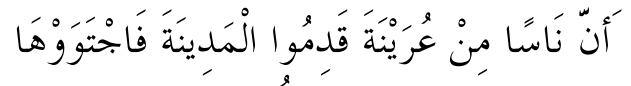

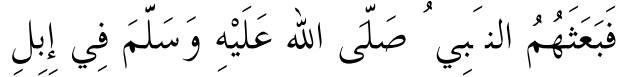

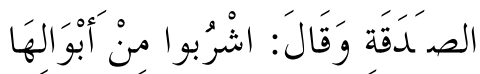

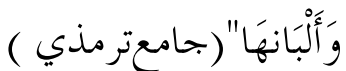

Artinya: "Kami diceritakan oleh Hasan bin Muhammad Azza'farani, dari 'Affan dari Hammad bin Salamah dari Humaid dan Tsabit dan Qatadah dari Anas berkata: sesungguhnya manusia dari 'Urainah masuk makkah dan Nabi memerihtahkan kami untuk memberinya unta sebagai sedekah. Bersabda Rasulullah: Minumlah kencing dan susu onta."

Hadis ini banyak diragukan keshahihannya. Beberapa ulama berkomentar bahwa hadis ini dha'if;

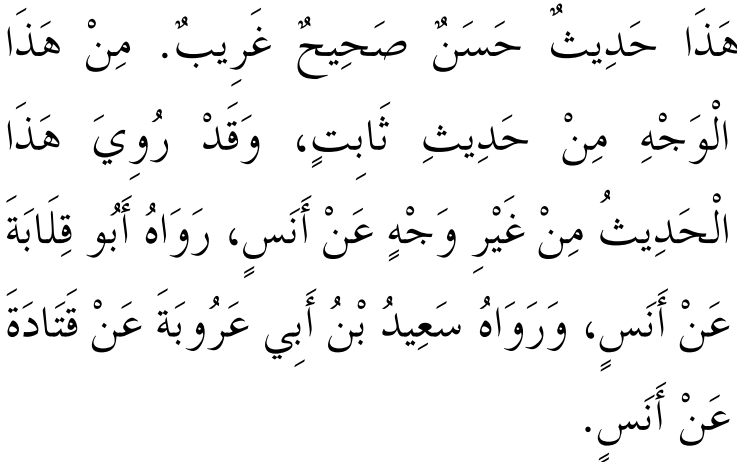

Hadis ini adalah hasan, shahih dan gharib. Beberapa ulama seperti Imam Al Bani berkata bahwa hadis ini dha'if

\footnotetext{
${ }^{12}$ Redaktur Aceh Tribun News, '7 Manfaat Susu Unta Untuk Kesehatan', 2018 - https://aceh.tribunnews.com/2018/07/13/7-
}

jiddan karena dua 'illat (sebab); pertama adalah kotor dan yang kedua karena nama Husain bin Qais adalah perawi yang ditinggalkan karena tidak tsiqqah (terpercaya). (Fathu al Bari)

Sementara itu dalam Al Imam Muhammad bin Ali bin Muhammad Assyaukani dalam Kitab Subulussalam berkomentar bahwa pengobatan menggunakan barang najis merupakan haram karena Rasul melarangnya. Dalam hadis lain Rasul mengatakan;

$$
\begin{aligned}
& \text { عن أبي هريرة رضي الله عنه: نهى رسول الله صلى } \\
& \text { الله عليه و سلم عن كل دو اء خبيث }
\end{aligned}
$$

Dari Abu Hurairar Ra: Rasul Saw. melarang seluruh obat yang kotor dan najis.

Terlepas dari perbedaan ulama' menyikapi hadis susu dan kencing onta sebagai obat, penulis ingin sedikit membahas tentang susu unta mungkin belum menjadi konsumsi bagi masyarakat Indonesia, karena sedikitnya species onta di negara ini. Padahal jika dibanding dengan susu lainnya kandungan susu ini lebih baik.

Dilansir Grid.ID dari laman Boldsky, "Perbandingan susu susu unta dari susu lainnya adalah lebih rendah kalori dan lemak jenuh. Dalam satu gelas susu unta terdapat 110 kalori dan 4,5 gram lemak, sementara itu, susu sapi miliki 150 kalori dan 8 gram lemak. Susu unta juga memiliki kandungan vitamin B3, vitamin $\mathrm{C}$ dan zat besi." 12

Mempunyai manfaat di antaranya adalah; mencegah anemia, mengobati diabetes, mendukung pertumbuhan dan perkembangan anak, mengobati autisme, meningkatkan kekebalan tubuh dan anti penuaan.

\section{e. Pengobatan Menggunakan Bekam}

Bekam beberapa kali dilakukan oleh Rasulullah sebagai sarana obat penurun

manfaat-susu-unta-salah-sat unya-bisa-untukpengobatan-autisme? page $=2$. 
sakin kepala dengan mengambil darah kotor yang ada di kepala. Hal ini sebagaimana yang ada dalam hadis berikut ini:

$$
\text { من أحتجم لسبع عشرة وتسع عشرة و وإحدى كشرين }
$$

"Barang siapa yang bekam selama 17 kali atau 19 kali atau 21 kali maka akan menyembukan setiap penyakit." (Sunan Abu Dawud 3861)

$$
\begin{aligned}
& \text { عن أنس قال رسول الله صلى الله عليه وسلم إن } \\
& \text { أفضل ما تداويتم به الحجامة }
\end{aligned}
$$

"Sesungguhnya pengobatan paling utama adalah bekam" (Sunan Turmudzi 2952)

Pengertian bekam menurut beberapa pakar kesehatan:

Teknis bekam atau yang dikenal sebagai hijamah adalah teknik pengobatan dengan cara mengeluarkan darah kotor dan racun yang berbahaya dari tubuh melalui permukaan kulit. Hijamah sendiri dari bahasa Arab yang berarti mengeluarkan darah dari dalam tubuh. ${ }^{13}$

Manfaat bekam sesuai yang dilansir pada sebuah artikel kesehatan bahwa bekam memiliki manfaat yang sangat banyak sekali. ${ }^{14}$ Di antaranya adalah; membuang racun, melancarkan peredaran darah, mengatasi kelelahan, meredakan nyeri, memperlancar peredaran darah pada tubuh.

\section{f. Pengobatan Talbinah (Bubur Gandum dicampur Madu) Untuk} Liver

Pengobatan tradisional Nabi yang berikutnya adalah bubur talbinah adalah gandum yang telah dijadikan tepung lalu dicampur dengan madu dan dijadikan bubur. Ini sesuai dengan sabda Nabi:

$$
\text { عن عائشة رضي الله عنها: أنها كانت تأمر بالتلبين }
$$

\footnotetext{
${ }^{13}$ dr. Ahmad Ali Ridha, Bekam Sinergis: Rahasia Pengobatan Nabi, Medis Modern Dcan Tradisional Chines Medicine (Solo: Aqwamedika, 2012).

${ }^{14}$ Fatimah Rahmawati, '5 Manfaat Bekam Bagi Kesehatan', 2020
}

$$
\text { يقول: ((إن التلبينة تجمٌّ فؤ اد المريض الله صلى الله عليه و آله وسلم وتذهب }
$$

"Dari 'Aisya Ra berkata: sesungguhnya Ummul Mu'minin 'Aisyah memerintahkan perempuan muslimah untuk membuat talbinah sebagai obat penyakit hati dan kesedihan. Karena beliau mendengar Rasul bersabda: "Sesungguhnya talbinah dapat mengobati penyakit hati dan meringankan sebagian kesedihan." (Shahih Bukhari no. 5365)

\section{g. Cendawan Atau Jamur Sebagai Obat Mata}

Obat herbal ala Nabi yang berikutnya adalah mengkonsumsi cendawan sebagai obat mata. Ini terdapat dalam hadis berikut ini:

$$
\begin{aligned}
& \text { وعن سعيد بن زيد قال: سمعت النبي صلى الله عليه } \\
& \text { و آله و سلم يقول: ((الكَّأة من المن، وماؤها شفاء } \\
& \text { للعين))؛ أخرجه البخاري رقم: (5381) }
\end{aligned}
$$

"Al Kam-at (cendawan) adalah di antara sejenis manna (sejenis makanan) yang diturunkan Allah kepada Musa, airnya mengandung obat bagi penyakit mata". (Shahih Bukhari No. 5381)

Jamur al-kam'ah atau al-faqa' (truffle) merupakan makanan yang kini digandrungi banyak orang. Selain memiliki rasa yang enak, harganya juga lumayan mahal. Bahkan, per kilogramnya dibandrol hingga Rp 120 juta. Jamur jenis ini banyak tersebar di Jazirah Arab.

$$
\text { Orang dahulu enggan }
$$
mengonsumsinya karena tampilan yang buruk. Namun, kini masyarakat memahami makanan ini mengandung gizi yang tinggi. Dalam hadis riwayat Bukhari, Muslim,

<https://www.merdeka.com/jabar/5-manfaatbekam-bagi-kesehatan-dan-efek-sampingnyakln.html?page $=6>$. 
Hamad, Tirmidzi, dan Ibnu Majjah, Rasulullah diketahui pernah menyinggung tentang jamur al-kam'ah.

Kandungan air di dalamnya dapat menyembuhkan sakit mata. Al-kam'ah dapat ditemukan dekat batang pohon besar. Biasanya, jamur ini tumbuh di dekat pohon ek. Bentuknya seperti umbi-umbian. Biasanya, dalam satu lokasi terdapat 20 hingga 30 buah jamur ini. ${ }^{15}$

\section{h. Pengobatan Dengan Dahan Kayu India}

Kayu India berkhasiat sebagai penyembuh radang paru-paru, sebagaimana dijelaskan Rasul dalam hadisnya:

$$
\begin{aligned}
& \text { وعن أم قيس بنت محصن رضي الله عنها قالت: } \\
& \text { سمعت النبي صلى الله عليه وآله وسلم يقول: } \\
& \text { (عليكم بهذا العود الهندي؛ فإنّ فيه سبعة أشفية، }
\end{aligned}
$$

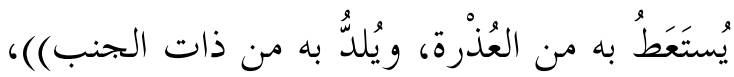

$$
\begin{aligned}
& \text { ودخلت على النبي صلى الله عليه و آله و سلم بابنٍ } \\
& \text { لي لم يأكل الطعام فبال عليه، فدعا بماء فرشَّ عليه؛ } \\
& \text { أخرجه البخاري رقم: (5368)، ومسلم رقم: }
\end{aligned}
$$

Artinya: Dari ummu Qais binti Mishan mengatakan: saya mendengar Nabi Saw bersabda: "Gunakanlah dahan kayu India, karena di dalamnya terdapat tujuh macam penyembuh dan dapat menghilangkan penyakit (racun) di antaranya adalah radang penyakit paru." Ibnu sam'an berkata dalam hadisnya; "karena sesungguhnya padanya terdapat obat dari tujuh macam jenis penyakit, di antaranya adalah radang paru (dada)." Lalu aku menemui Nabi Saw. yang membawa bayiku yang belum makan makanan, maka beliau dikencingi anakku. Beliau meminta air

\footnotetext{
${ }^{15}$ Ratna Ajeng Tejomukti, 'Tiga Manfaat Jamur Al Kam'ah', Republika, 2019 <https://www.republika.co.id/berita/povpvz458/tiga -manfaat-jamur-alkamah>.
}

untuk dipercikkan ke pakaiannya. (Shahih Bukhari: 5368)

Gaharu adalah kayu berwarna kehitaman dan mengandung resin khas yang dihasilkan oleh sejumlah spesies pohon dari marga/genus Aquilaria, terutama Aquilaria malaccensis. Resin ini digunakan dalam industri wangi-wangian (parfum dan setanggi) karena berbau harum.

Selain untuk minyak wangi, kayu India ini dipercaya mampu menyembuhkan penyakit radang paru-paru, sistem pernafasan, insomnia, mengurangi sembelit, meredakan masalah ginjal, mengontrol kandungan gula darah, stress, asma, liver, radang lambung, radang usus, rhematik, tumor dan kanker.

Tumbuhan ini daunnya juga dapat dibuat teh dengan senyawa aktifnya yang mampu menekan sistem syaraf sehingga memberi efek ketenangan. Teh daun gaharu ini juga dapat dijadikan sebagai obat anti mabuk. Aromanya yang harum menjadikan kayu gaharu sabagai pilihan untuk dijadikan kamfer alami serta pengusir nyamuk. ${ }^{16}$

Penyakit maag kronis yang sering kambuh dapat diobati dengan cara mengambil kulit pohon gaharu sekitar 100 gram. Kemudian dicuci bersih lalu direbus dalam air sebanyak 2 gelas sampai air tersebut menyusut menjadi satu gelas. Air rebusan ini diminum sebanya dua kali sehari dalam dua hari berturut-turut, maka sakit maag itu akan berkurang.

Cara ini juga mampu mengatasi mual dan muntah, demam panas, malaria, lumpuh, reumatisme, sakit perut, melancarkan pembuangan air kecil dan penawar saat ibu hamil dan setelah melahirkan.

Gaharu mengandung olibanol, materi resin, dan terpenes. Kandungan lain,

\footnotetext{
${ }^{16}$ Nurjamal, 'Anjuran Nabi, Ini Khasiat Kayu India Bagi Kesehatan', Gomuslim.Co.Id, 2019 https:/gomuslim.co.id/read/khazanah/2019/01/26/1 0291/-p-anjuran-Nabi-ini-khasiat-kayu-india-bagikesehatan-nbsp-p-.html>.
} 
saponin, flavonoida dan polifenol. Dan kini para ilmuwan telah mengamati bahwa ada kandungan dalam Gaharu yang menghentikan penyebaran kanker. Namun, belum diketahui secara pasti kemungkinan Gaharu sebagai anti kanker.

Pada abad kesepuluh, Ibnu Sina, ahli pengobatan Arab, merekomendasikan Gaharu sebagai obat untuk tumor, bisul, muntah, disentri dan demam. Dalam pengobatan tradisional Cina, Gaharu digunakan untuk mengobati masalah kulit dan pencernaan. Sedangkan di India, Gaharu digunakan untuk mengobati arthritis.

Khasiat Gaharu sebagai obat arthritis tersebut mendapat dukungan dari penelitian laboratorium di Amerika Serikat. Gaharu yang biasa digunakan untuk urusan mistis ternyata berdasarkan hasil penelitian juga mampu menurunkan kadar kolesterol jahat.

Penelitian yang dilakukan oleh King Abd Al-Aziz University di Arab Saudi menemukan bahwa Gaharu bisa menurunkan kadar kolesterol jahat. Gaharu, menurut peneliti Nadia Saleh Al-Amoudi, bisa dipadukan dengan materi dari tumbuhan lainnya untuk meningkatkan kesehatan jantung.

\section{i. Pengobatan}

\section{Ruhaniyah Ala Nabi.}

Rasul Saw. selalu memerintahkan sahabat-sahabatnya untuk berobat dengan al-Qur'an dan memperbanyak do'a. Do'ado'a ini banyak sekali yang telah dikumpulkan oleh para ulama' dalam kitab khusus do'a ma'tsurah.

Hal ini seperti yang disampaikan oleh Rasulullah dalam hadisnya;

$$
\text { شفاء إلا شفاءك الباس، رب الناس اشف وأنت الشافي، ل U لغادر سقما }
$$

"Aku menghilangkan penyakit dengan mengatakan "Wahai Allah, Tuhan manusia, sembuhkanlah karena engkaulah Dzat Penyembuh, tidak ada kesembuhan kecuali kesembuhan darimu. (Sunan Abu
Dawud no. 3890)

Dalam hadis lain Rasulullah juga meniupkan tangan dengan menggunakan ma'udzat (Surat Al Falaq dan Annas) lalu mengusapkan ke wajahnya hal ini yang disampaikan oleh Sayyidina A'isyah yang mengatakan bahwa beliau jika ada yang sakit maka beliau meminta perlindungan kepada Allah atas penyakit yang dideritanya atau diderita orang lain dengan cara meniupkan tangan bersama itu membaca ma'udzat. (Shahih Bukhari 5735)

Sayyidah 'Aisyah juga bercerita jika Rasul mengajari do'a yang dipanjatkan untuk orang yang sakit:

$$
\text { بشفى الله، تربة أرضينا، وريقة بعضنا، }
$$

(Shahih Bukhari 5746)

Rasul dalam hadis lain juga berdoa agar dihindarkan Allah dari empat hal; ilmu yang tidak bermanfaat, hati yang tidak khusyu', do'a yang tidak diijabahi Allah dan dari perut yang tak pernah merasa puas. (Sunan Annasa'I no. 5444)

$$
\begin{aligned}
& \text { اللهم أعوذبك من علم لU ينفع وقلب لا يخشع ومن } \\
& \text { دعاء لا يسمع ومن نفس لا تشبع. }
\end{aligned}
$$

Dari hadis-hadis di atas dapat kita simpulkan bahwa Rasulullah Saw selalu mengajarkan ummatnya untuk menjaga diri dari penyakit badan dan penyakit hati.

\section{Simpulan}

Setelah kita mengetahui betapa pentingnya kesehatan yang telah digariskan Rasulullah kepada Ummatnya, dapat kita simpulkan dari hadis-hadis yang telah dikumpulkan oleh penulis terdapat ada 8 obat herbal Thibbbunnabawi yang di antaranya adalah: minum madu dapat melancarkan aliran darah, bekam mengobati darah kotor yang mengental dalam otak, kayu India (Gaharu) menyembuhkan, cendawan (jamur Arab) sebagai obat mata, talbinah (bubur gandum campur madu) melancarkan percernaan, 
susu onta sebagai anti bodi dan pertumbuhan anak dan tentulah do'a sebagai usaha batiniyah seorang muslim. Tentu kesembuhan adalah milik Allah, namun usaha untuk menjaga kesehatan adalah kewajiban seluruh manusia. Karena kesehatan adalah amanah yang harus selalu kita jaga sampai kapanpun.

\section{DAFTAR PUSTAKA}

Anisa, Salis, 'No Title', Sehatq.Com, 2020 https://www.sehatq.com/artikel/komp res-penurun-panas-dan-cara-lainuntuk-mengatasi-panas-demam

Dahlawi, Syah Wali al, Hujjah Al Balgihah (Cairo: Dar el Jail, 2020)

Dr. Fathi Al duraini, 'Al Manahij Al Ushuliyyah Fi Al Ijtihad Bi Al Ra'yi Fi Tasyri' Al Islami' (Cairo: Muassasah al Risalah)

Fatahilah, Muhammad, 'Klinik Pengobatan Thibbun Nabawi Di Kota Pontianak', Jurnal Online Mahasiswa Arsitektur Universitas Tanjungpura, 4.2 (2016), 109

Muhammad Sulaiman Al Asyqar, Al Azhar أفعال Univ. Cairo, 'Noor-Book.Com الرسول صلى الله عليه وسلم ودلالتنها على الأحكام (Cairo: Muassasah al Risalah)

Mundzir, Ibnu, Lisan Al Arab (Bairut: Dar el Shadir)

News, Redaktur Aceh Tribun, '7 Manfaat Susu Unta Untuk Kesehatan', 2018 https://aceh.tribunnews.com/2018/07/ 13/7-manfaat-susu-unta-salahsatunya-bisa-untuk-pengobatanautisme?page $=\overline{2}$

Nurjamal, 'Anjuran Nabi, Ini Khasiat Kayu India Bagi Kesehatan', Gomuslim.Co.Id, 2019 https://gomuslim.co.id/read/khazanah /2019/01/26/10291/-p-anjuran-Nabiini-khasiat-kayu-india-bagikesehatan-nbsp-p-.html

Qardhawi, Dr. Yusuf al, 'Dirasah Fi Al
Fiqhi Maqasid Al Syari'ah' (Cairo: Dar el Syuruq)

Rahmawati, Fatimah, '5 Manfaat Bekam Bagi Kesehatan', 2020 https://www.merdeka.com/jabar/5manfaat-bekam-bagi-kesehatan-danefek-sampingnya-kln.html?page $=\overline{6}$

Ridha, dr. Ahmad Ali, Bekam Sinergis: Rahasia Pengobatan Nabi, Medis Modern Dcan Tradisional Chines Medicine (Solo: Aqwamedika, 2012)

Safarsyah, Alfandi Ilham, 'Hadis Nabi SAW Tentang Obat Dalam Tinjauan Ilmu Kedokteran Modern', Al-Dzikra: Jurnal Studi Ilmu Al-Qur'an Dan AlHadis, $12.2 \quad$ (2019), 165-88 https://doi.org/10.24042/aldzikra.v12i2.2079

Sartika, Resa Eka Ayu, 'No Title', 2020 https://health.kompas.com/read/2020/ 07/08/193400368/10-manfaat-maduunt uk-kesehat an-tubuh?page $=$ all

Tejomukti, Ratna Ajeng, 'Tiga Manfaat Jamur Al Kam'ah', Republika, 2019 https://www.republika.co.id/berita/po vpvz458/tiga-manfaat-jamur-alkamah

Ujjaj, Dr. Muhammad, Ushulu Al Hadis (Bairut: Dar al Fikr)

Abu Bakar Ahmad bin al Husain bin Ali al Baihaqi, 'Sunan Kubra', Bairut; Dar al Kutub al Ilmiyyah.

Abu Isa Muhammad bin Isa Atturmudzi," "Jami' al Turmudzi', Bairut; Dar Al Kutub al Imlyyah

Ahmad Muhammad bin Hambal, 'Musnad Ahmad bin Hambal' Cairo: Dar el Hadis)

Al Imam Malik bin Ahmad, 'Muwatta' Malik' Cairo; Dar an Nawadir

Al Imam al Hafidz Syihabuddin Ahmad bin Ali bin Hajar al 'Astaqalani, 'Fathul Bari Sharakh Shahih Bukhari'Bairut; Dar Al Kutub al Ilmiyyah

Al Imam Taqiyuddin ibnu Taimiyyah, 'Fatawi Kubra', Bairut; Dar Al Kutub al Ilmiyyah 2008. 